\title{
REVIEW
}

\section{VOLATILES PRODUCED BY INTERACTING MICROORGANISMS POTENTIALLY USEFUL FOR THE CONTROL OF PLANT PATHOGENS}

\author{
Voláteis produzidos pela interação entre microorganismos potencialmente \\ úteis no controle de fitopatógenos
}

\author{
Vicente Paulo Campos ${ }^{1}$, Renata Silva Canuto de Pinho², Eduardo Souza Freire ${ }^{2}$
}

\begin{abstract}
The results of studies about interactions between microorganisms involving at least one plant pathogen are of interest to the areas of ethiology and control in Plant Pathology. Various aspects of these interactions have been studied over the years but the toxicity of volatile organic compounds (VOCs) has been emphasized only recently, developing techniques and procedures, and producing additional knowledge to those already obtained with water-soluble substances. This new facet of these interactions based on VOCs is discussed in this review involving mainly fungi, bacteria and nematodes pathogenic to plants. Also discussed is the role of VOCs produced by microorganisms, especially fungi and bacteria, in soil fungistasis and the effect of VOCs on fungal agents used in the control of plant parasitic nematodes. The evidence of VOCs broadens the research studies about these interactions. However, the scarcity of the research results in this area show up gaps which need to be filled and some research proposals are discussed. The present and future accumulated VOC knowledge will perhaps be beneficial to farmers, especially aspects related to increasing soil suppressiveness to plant disease and to the finding of analog molecules of VOCs highly effective against plant pathogens.
\end{abstract}

Index terms: Biological control, volatiles, plant pathogens, interaction.

\begin{abstract}
RESUMO
Os resultados dos estudos sobre interações entre microorganismos quando envolve, no mínimo, um patógeno de plantas são de interesse às áreas de etiologia e controle de fitodoenças. Vários aspectos dessas interações têm sido, por muitos anos, estudados, porém, a toxicidade de compostos orgânicos voláteis (COV) tem sido enfatizada apenas recentemente, desenvolvendo-se técnicas e rotinas, além de produzir conhecimentos adicionais àqueles já obtidos por meio de pesquisas com substâncias solúveis em água. Essa nova faceta dessas interações, envolvendo COVs, é discutida nesta revisão, enfatizando, principalmente, o antagonismo a fungos, bactérias e nematóides patogênicos de plantas. Também é discutido o papel dos COVs produzidos por microorganismos especialmente, fungos e bactérias envolvidos na fungistase do solo, bem como o efeito dos COVs nos agentes fúngicos usados no controle de fitonematóides. A evidência comprovada dos COVs nessas interações amplia esse campo de pesquisa. Entretanto, a escassez de pesquisas nessa área afloram lacunas no conhecimento científico que precisam ser preenchidas e, desta forma, algumas propostas de pesquisas são discutidas. O conhecimento científico presentemente acumulado nessa área de pesquisa, juntamente com aquele a ser produzido, serão, talvez, úteis aos produtores rurais, especialmente nos aspectos envolvendo a constatação de supressividade de solo a fitodoenças e aos testes com moléculas análogas dos COVs altamente tóxicos a patógenos de plantas.
\end{abstract}

Termos para indexação: controle biológico, voláteis, patógenos de plantas, interações.

(Received in april 15, 2010 and approved in april 23, 2010)

\section{Introduction}

Interactions between microorganisms are affected by watersoluble - and volatile - molecules, however, only volatile compounds will be discussed here.

In ecosystems, plants compensate for their immobility by releasing volatile substances into the atmosphere and from roots into the soil constituting about $1 \%$ of secondary plant metabolites. These volatile substances promote plant communication and interaction with the surrounding environment (Dudareva et al., 2006). The vast majority of studies examining the efflux of volatile organic compounds (VOCs) from terrestrial ecosystems has focused on the production of such substances by plants (Kesselmeier \& Staudt, 1999), which, according to Knudsen \& Gershenzon (2006), can produce more than 1700 VOCs. However, soil and litter also produce VOCs, mostly by soil bacteria and fungi (Isidorov \& Jdanova, 2002; Left \& Fierer, 2008). Volatile compounds are typically lipophilic liquids with high vapor pressures. They cross

${ }^{1}$ Federal University of Lavras/UFLA - Department of Plant Pathology - Laboratory of Plant Nematology - P.O. Box 3037 - $37200-000$ - Lavras, MG - Brazil vpcampos@ufla.br

2Federal University of Lavras /UFLA - Department of Plant Pathology - Laboratory of Plant Nematology - Lavras, MG - Brazil 
membranes freely and are released into the atmosphere or soil in the absence of a diffusion barrier (Pichersky et al., 2006), as well as diffusing through aqueous solution movement and mass flow of water through the soil profile causing rapid movement of these volatiles throughout the system (Wheatley, 2002). Easya membrane penetration and efficient distribution through soil porosity by volatiles enlarge the volatile area of influence and improves death efficacy of the target microorganism from the control point of view. Therefore, volatiles not only play a role above ground but also function below ground. Thereafter fumigant nematicides kill the nematodes, resulting in the interruption of their life-cycle. By comparison, watersoluble organophosphate and organocarbamate nematicides immobilize the target nematode and retard its life-cycle (Sikora et al., 2005).

Emission of volatiles by bacteria and fungi has been known and reviewed by many authors for a long time (Stotzky $\&$ Schenck, 1976; Kai et al., 2009). Volatile production is species-specific and serve as (1) infochemicals for interand intraorganismic communication, (2) cell-to-cell communication signals, (3) a possible carbon release valve, or (4) growth-promoting or inhibiting agents (Kai et al., 2009). The inhibitory mode of action, when it involves one plantpathogen microorganism among interacting organisms, will be of interest to researchers in areas such as Plant Pathology, soil suppression, biological control and Nematology, among others.

Although non-volatile substances toxic to plant pathogenic microorganisms have been extensively studied over the years, few papers have focused on the volatileproducing substances by microorganisms against plant pathogens in the last 10-15 years (Mackie \& Wheatley, 1999; Strobel et al., 2001; Fernando et al., 2005; Gu et al., 2007; Zou et al., 2007; Wan et al., 2008). The new techniques and tools available, besides the necessity to advance the understanding of the interacting organisms, have motivated researchers to look for volatiles as an additional way to explain the co-existence of microorganisms resident in the same site, adding new insights to the accumulated knowledge of non-volatile substances, and thus opening new frontiers on the relationship among VOC-based organisms.

Due to the complexity of VOC research, this review is not intended to be entirely comprehensive. Instead, we will focus on VOCs produced by microorganisms which interfere with those pathogenic to plants causing antagonistic interaction among them and by drawing a perspective of success, or not, when a biological control agent is introduced in the site occupied by other residents.

\section{Tools used for VOC studies}

Studies on volatiles have to be done in sealed environments. For the entire plant studies the apparatus can be costly. Simple techniques have been used for the microorganism interaction studies. Among those, Fernando et al. (2005), used compartmented Petri dishes. Strobel et al. (2001), used a $9 \mathrm{~cm}$ Petri dish with cultural medium. One test microorganism is placed on one side, a central strip of medium is removed and the other tested microorganism is placed on opposite side of the dish. Bruce et al. (2003), cultured each microorganism in separate Petri dishes. To set up the assay, the Petri dish lids were removed, cultured microorganism dishes were inverted over each other, being the lid one of them, sealed and incubated. Riga et al. (2008), used a special sealed chamber described Lacey \& Neven (2006) (28.3 L, Lab conco vacuum desicators model 5530, Kansas City, MO). For more details see some original and recent papers listed in the references.

Gas chromatography / mass spectrometry (GC/MS) is useful for VOC identification from microorganisms cultured in sterilized glass vials sealed with silicone septas.

\section{Nematicidal activities of VOC substances from bacterial isolates}

Very few researchers have tested VOCs from bacterial isolates on the nematode antagonism. To our knowledge, until now, tests have been conducted mostly in vitro, evaluating second stage juvenile $\left(\mathrm{J}_{2}\right)$ immobility, mortality and egg-hatching resulting from VOC exposure without additional infectivity or reproduction evaluation in infected plant with VOC-exposed plant-parasitic nematodes. Gu et al. (2007), using compartmented Petri dishes, tested 200 bacterial isolates against Panagrellus redivivus - a free-living nematode - and found nematicidal activities (NA) (immobility) above $20 \%$ from 149 isolates. Some of them (49 isolates) caused more than $80 \%$ NA including Bacillus weihentephanensis, B. simplex, B. subtilis, Serratia marcences. Those bacterial isolates were also tested against Bursaphelenchus xylophilus, a total of 165 bacterial isolates showed greater than $20 \%$ NA (immobility). However, $6.5 \%$ of the total tested isolates showed strong NA (>80\%), including B. simplex, $B$. subtilis, B. weihentephanensis, Stenotrophomonas maltophilia, and Serratia marcences. Six bacterial isolates (two of B. simplex, three of weihentephanensis and one of $S$. marcences) demonstrated strong NA (NA $\geq 80 \%$ ) against both tested nematode species. Huang et al. (2010), found that Bacillus megaterium VOCs caused strong death $(100 \%)$ of Meloidogyne incognita $\mathrm{J}_{2}$ and strong egghatching inhibition (Table 1). 
Table 1 - Nematicidal activities (NA) of bacterial isolate VOCs against nematodes.

\begin{tabular}{|c|c|c|c|c|c|}
\hline \multirow{3}{*}{ Bacterial species } & \multicolumn{5}{|c|}{ Isolate number of each bacterial species against target nematodes } \\
\hline & \multicolumn{2}{|c|}{$\begin{array}{l}\text { Panagrellus } \\
\text { redivivus }{ }^{(1)}\end{array}$} & \multicolumn{2}{|c|}{$\begin{array}{l}\text { Bursaphelenchus } \\
\quad \text { xylophilus }^{(1)}\end{array}$} & \multirow{2}{*}{$\begin{array}{c}\begin{array}{c}\text { Meloidogyne } \\
\text { incognita }^{(2)}\end{array} \\
100 \% \text { NA }\end{array}$} \\
\hline & $100 \% \mathrm{NA}$ & Above $20 \%$ NA & Above $80 \%$ NA & Above $20 \%$ NA & \\
\hline Bacillus simplex & 6 & 37 & 3 & 44 & 0 \\
\hline B. subtilis & 7 & 56 & 4 & 59 & 0 \\
\hline B. weihenstephanensis & 8 & 52 & 4 & 58 & 0 \\
\hline B. megaterium & 0 & 0 & 0 & 0 & 1 \\
\hline Serratia marcences & 1 & 0 & 1 & 1 & 0 \\
\hline $\begin{array}{l}\text { Stenotrophomonas } \\
\text { maltophilia }\end{array}$ & 0 & 1 & 1 & 1 & 0 \\
\hline Microbacterium oxydans & 0 & 0 & 0 & 1 & 0 \\
\hline Streptomyces lateritius & 0 & 0 & 0 & 1 & 0 \\
\hline
\end{tabular}

Obtainned from (1) Gu et al. 2007; (2) Huang et al. 2010.

Bacterial species and isolates of the same species seem to have significant variations in nematicidal capability of the VOCs.

\section{Nematicidal activities of VOC substances from fungal isolates}

By using a special chamber described by Lacey \& Neven (2006) (28.3 L, Labconco vacuum desiccators, model 5530, Kansas City, MO), Riga et al. (2008), tested VOCs produced by the fungus Muscodor albus and found in vitro mortality of Paratrichodorus allius, Pratylenchus penetrans and Meloidogyne chitwoodi ranging from 82 to $95 \%$, but for M. hapla, its VOCs caused a $69.5 \% \mathrm{~J}_{2}$ motility reduction. In another assay, soil was mixed with $M$. albus formulation added nematode inocula and was hermetically closed in plastic containers. Seven days later, one appropriate seedling was planted per pot. Population reduction of Pratylenchus allius, $P$. penetrans, $M$. chitwood and $M$. hapla varied from $85 \%$ to $100 \%$ in roots and from $56 \%$ to $100 \%$ in the soil. Thus, the M. albus VOCs demonstrated nematostatic and nematicidal properties.

Freire et al. (2010), using compartmental Petri dishes tested several fungal isolate VOCs against $M$. incognita $\mathrm{J}_{2}$ and found very strong immobility (above 78\%) of 6 isolates of Fusarium oxysporum. Among those, two isolates caused very strong $\mathrm{J}_{2}$ mortality. They also found VOCs from one $F$. solani isolate which caused very strong $\mathrm{J}_{2}$ immobility and mortality (Table 2). The increased exposure time of $M$. incognita $\mathrm{J}_{2}$ to VOCs from $F$. oxysporum isolate 21 decreased their infectivity to tomato roots.

\section{VOC identification with nematicidal activities using GC/MS}

VOCs from bacteria and fungi usually contain a mixture of compounds which may be more effective to control nematodes.

\section{From bacterial isolate}

Among 81 distinct VOC substances detected in the 15 bacterial isolates by Gu et al. (2007), 46 VOCs were not considered to have any NA because they were present in all tested bacterial isolates and as well as in the medium (control) with similar abundance. Among the remaining 36 VOCs, 18 were produced by bacteria with strong NA and two VOCs (benzaldehyde and trimethylpyrazine) occurred in all samples at high concentrations, amounting to $20 \mathrm{VOC}$ substances which were tested against Panagrellus redivivus and B. xylophilus to confirm the suspected NA using individual commercial compounds. Among those, 9 showed 100\% NA against tested nematodes and were all present in the VOCs of isolates from both Bacillus simplex and $B$. subtilis. The commercial tested molecule analogs to the 9 VOCs were: 2-undecanone, 2-octanol, decanol, benzaldehyde, 2-nonanone, dimethyl disulfide, benzeneacetaldehyde, cyclohexene and phenol. Benzaldehyde and 2-undecanone were produced by $S$. marcescens and St. maltophilia produced phenol, benzaldehyde, benzeneacetaldehyde, 2-undecanone and dimethyl dissulfide. None of the VOCs were produced specifically by only one bacterium. From Bacillus megaterium 17 VOC substances were identified by Huang et al. 2010. These substances were tested in vitro, against 
M. incognita by using commercial compound analogs. Five of those (2- noanone, 2-undecanone, decanal, dimethyl disulfide, benzeneacetaldehyde) demonstrated strong nematicidal activities (NAs $\geq 80 \%$ ).

Many VOC compounds with nematicidal activity also have fungicidal activity (Xu et al., 2004; Fernando et al., 2005). Although described bacterial-volatile emissions comprise 346 different compounds (Schulz \& Dickschat, 2007), most of them need to be tested against plant-parasitic nematodes looking for inhibitory aspects. But the bacterial volatiles have turned out to be a rich source of new natural compounds, comparable in their diverse complexity to those known for plants and fungi.

\section{From fungal isolate}

47 VOC substances were identified by Freire et al. (2010) from Fusarium oxysporum isolate 21, which showed very strong immobility and mortality to $M$. incognita $\mathrm{J}_{2}$ and reduced infectivity by inoculated $\mathrm{J}_{2}$ after exposure to VOCs of $F$. oxysporum isolate 21 . The major VOC substances were: caryophyllene (22\%), 4-methyl-2,6-di-tertbutylphenol (3.8\%), 1-(1,1-dimethylethyl)-2-methyl-1,3propanediyl-2- methylpropanoate $(2.5 \%)$, acoradiene (3.1\%).

\section{Fungicidal activities of VOC substances from bacterial isolates}

Bacterial antagonism to the growth of plant pathogenic microorganisms through antibiosis has been the main mechanism of the biological control agent. However, another and additional potential mode of action may lie in the production of antifungal volatile metabolites recently emphasized by researchers, although little attention was given to them in the past (Moore-Landecker \& Stotzy, 1972).

Fungicidal activity (FA) VOCs from bacterial isolates may be lower in some cases, than nematicidal effects. Freire et al. (2010), found FA VOCs of bacterial isolates low (15\% to $26 \% \mathrm{FA}$ ) to moderate (from $28 \%$ to $53 \% \mathrm{FA}$ ) against $F$. oxysporum and Arthrobotrys conoides, respectively (Table 2). Zou et al. (2007) isolated 1018 bacterial isolates from the soil. From those, 328 isolates showed inhibitory effect against conidial germination and mycelial growth to varying degrees of Paecilomyces lilacinus and Pochonia chlamydosporia.

Bacteria isolated from canola and soybean plants produced antifungal VOCs which inhibited sclerotia and ascospores germination, and micelial growth of Sclerotinia sclerotiorum in vitro and in soil tests. Of the 197 bacterial isolates obtained, 14 inhibited mycelial growth and sclerotial germination of $S$. sclerotiorum. Among those 14 isolates, 10 were identified to species level: Pseudomonas chlororaphis (5 isolates), $P$. corrugate (1 isolate), $P$. fluorescens ( 3 isolates) and $P$. aurantiaca ( 1 isolate) (Table 2) (Fernando et al., 2005).

Release of cyanide by Pseudomonas fluorescens CHAO controls tobacco rot caused by the fungus Thielaviopsis basicola (Voisard et al., 1989).

Bacterium species Paenibacillus polymyxa, Bacillus pumillus and B. subtilis, isolated from cucumber rhizosphere soil produced VOCs that inhibited the growth (from $20 \%$ to $100 \%$ ) of Sclerotinia sclerotiorum, Botrytis cinerea, Alternaria brassicae, A. solani, Ascochyta citrullina, Fusarium oxysporum, F. graminerum, Cercospora kikuchii, Rhyzoctonia solani, Phoma arachnidicola, Verticillium dahiae. Therefore, it appears that these volatiles have the potential ability to reduce fungal infection (Liu et al., 2008) (Table 2).

Bacillus subtilis and B. amyloliquefaciens isolated from valencia and shamouti oranges produced VOCs with growth-inhibition capacity (from $25 \%$ to $50 \%$ ) of Penicillium crustomosum and P. italicum (Arrebola et al., 2010) (Table 2).

Bacillus subtilis inhibited the growth of Rhizoctonia solani, Pythium ultimum, Botrytis cinerea, Fusarium avenacerum, F. solani, F. culmorum, Sclerotinia sclerotiorum, Alternaria brassicola, Leptosphaeria maculans with different levels of FA (Fiddaman \& Rossall, 1994). Kai et al. (2007), also found inhibition of Rhizoctonia solani growth by Serratia plymuthica, S. odorifera, Stenotrophomonas maltophila, $S$. rhizophila, Pseudomonas fluorescens and P. trivialis (Table 2). Vespermann et al. (2007), reported on the growth inhibition by $40 \%$ or more of Microdochium bolleyi, Paecilomyces carneus, Phoma betae and Sclerotinia sclerotiorum by bacterial isolates. Mackie \& Wheatley (1999), tested more than 60 bacterial isolates obtained from cultivated soil for VOC production. About $42 \%$ of the tested bacterial isolates caused fungal growth inhibition. Among them there were isolates with inhibition of Phanaerochaete magnoliae $(84 \%)$ and Trichoderma viride $(65 \%)$ growth, but fewer of the bacterial isolates had an effect on Phytophthora cryptogea or Gaeumannomyces graminis var. tritici. However, the bacterial species were not recognized.

Streptomyces platensis F-1 VOCs reduced mycelial growth of $R$. solani, $S$. sclerotiorum and $B$. cinerea, and controlled the disease caused by them in rice, oilseed rape and strawberry, respectively (Wan et al., 2008) (Table 2). 


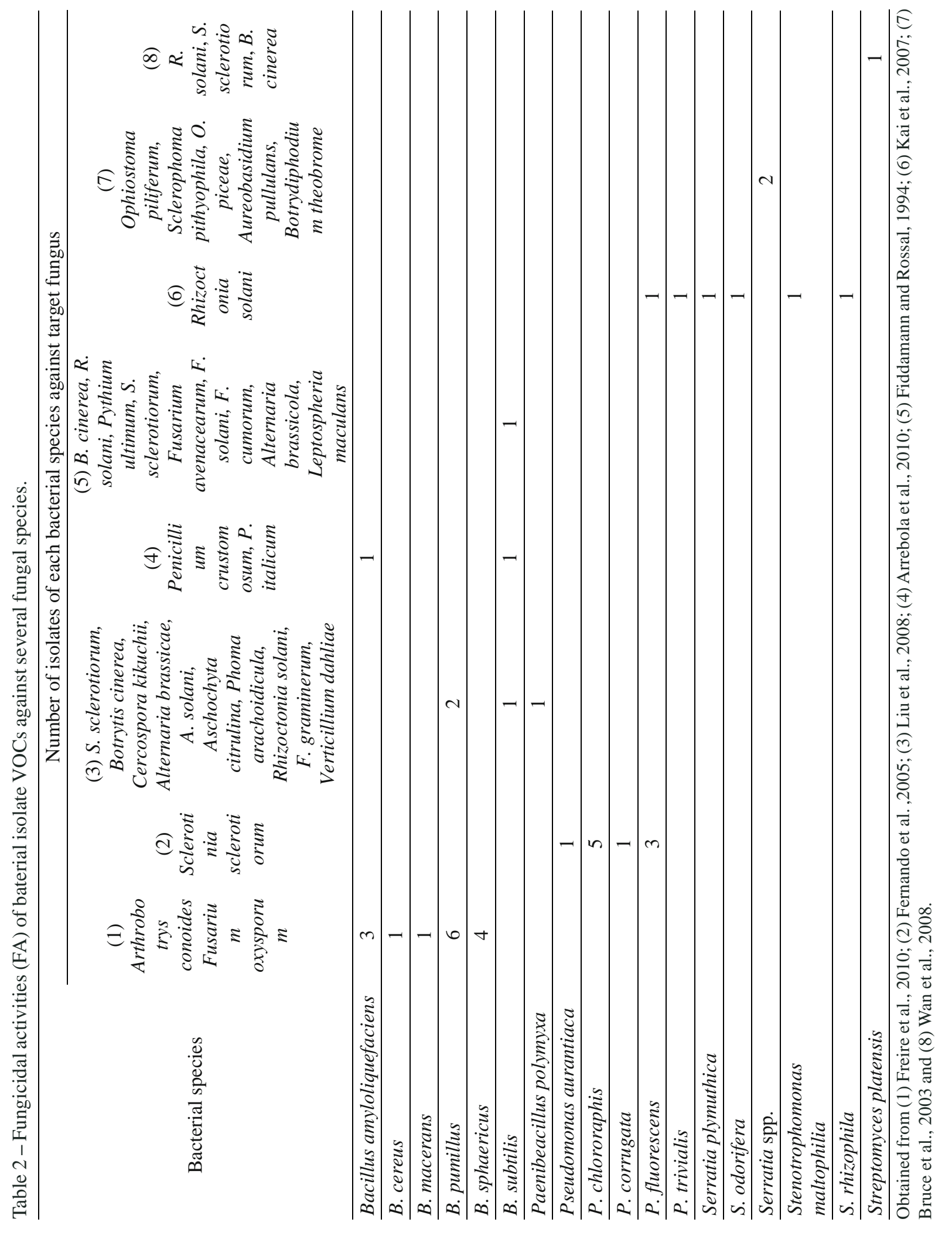


Many researchers have obtained variations on FA values of each fungal species among isolates from the same bacterial species and no single bacterial isolate is effective, against all of the tested fungi (Mackie \& Wheatley, 1999). The responses depend on the specific fungi-bacteria combination, because: (1) different fungi may respond to different component(s) of the volatile mixture, or (2) the reaction sites may be different, or (3) the fungi might possess different abilities to detoxify the volatile metabolite (s) (Kai et al., 2007).

A fairly good number of bacterial species VOCs causes antagonism to fungal species (Table 2). However, the number of antagonic bacterial species can be even higher since the bacterial species were not recognized among efficient isolates by some researchers, which is evidence for the great efficacy of bacterial VOCs in fungus antagonism.

The fungistatic effect attributable to bacterial volatiles has been substantiated during the past 10 years (Kai et al., 2009). Bacterial VOCs effect both fungal mycelial growth and enzyme activity (Wheatley, 2002).

The production of inhibitory VOCs against specific target fungi involves a combination of a specific bacterial species and growth medium types (Bruce et al., 2003). Fungal response to the bacterial VOCs appear to be speciesenvironment- and age-specific, both for the fungus and the bacteria (Mackie \& Wheatley, 1999), essential requirements for a signaling system.

Optimum VOC concentrations are required within a system for these compounds to be effective. Thus, exposure to both larger and older bacterial populations greatly increases both the degree and the rate of inhibitory effects on the fungi (Mackie \& Wheatley, 1999).

VOCs can be fungicidal or fungistatic and watersoluble. Mackie \& Wheatley (1999), found that the inhibitory effects on many fungi by the bacterial VOCs were not fungicidal and the persistence of the effects due to VOC adsorption into agar medium indicated that the active compounds are water-soluble.

VOCs produced by microorganisms played an important role during their evolution in the context of their interactions, community population and functional dynamics. Such interactions will result in functional responses by the organisms involved to some community members and coincidental disadvantage to others. The substrate - dependent variation in VOC production will result in variations in microbial, and consequently systemic, response (Wheatley, 2002).

\section{Fungicidal activities of VOC substances from fungal isolates}

Some attention has been given to the volatile compounds of fungal cultures over the years (Dennis \& Webster, 1971), without performing a comprehensive chemical analyses of the VOC components (Strobel et al., 2001). But their effect on plant pathogenic fungi has been emphasized only recently.

Muscodor albus VOCs inhibited by $100 \%$ the growth of fungi: Pythium ultimum, Phytophthora cinnamomi, Rhizoctonia solani, Ustilago hordei, Stagnospora nodorum, Sclerotinia sclerotiorum, Aspergillus fumigatus, Verticillium dahliae, Tapesia vallundae, Candida albicans and by $75 \%$ to $82.5 \%$ the fungi $F$. solani, Cercospora beticola and Xilaria sp., as well as decreasing seed fungus contamination of wheat $(T$. aestivum), chick-pea (Cicer arietinum), corn (Zea maydis), barley (Hordeum vulgare) and canola (Brassica napus) when the seeds were placed in closed chambers (storage) along with the fungus. The $M$. albus volatile compounds should be considered as potential agents for the treatment and control of pathogens affecting seed and plant parts in storage (Ezra \& Strobel, 2003), besides also being effective against bacterial growth.

In another experiment, Mercier \& Jimenez (2004) found that M. albus VOCs inhibited the growth of Botrytis cinerea, Colletotrichum acutatum, C. coccodes, Geotrichum candidum, Monilinia fructicola, Penicillium digitatum, Rhizopus sp. - the storage pathogens.

The fungus code denominated Kyu - w63, pot cultured on PDA medium and then placed at $30 \mathrm{~cm}$ intervals in the center of each ridge of parsley plants, controlled the parsley powdery mildew disease caused by Odium sp. by its VOCs (Koitabashi, 2005).

The yeast species Williopsis mrakii VOCs caused growth inhibition (from $20 \%$ to $100 \%$ ) of wood-sapstain fungi Ophiostoma piliferum, O. piceae, Sclerophoma pthyophila, Aureobasidium pullulans and Botrydiplodium theobrome. Lesser fungus-growth inhibition was caused by yeast species VOCs of Saccharomyces cerevisiae and Debaryomyces sp.. Different target sapstain fungi, however, showed varying sensitivities to the effects of the VOCs from the yeast (Bruce et al., 2003).

M. albus grown in richer media produce VOCs with higher inhibitory and killing effect capacity of the test organisms. Higher sucrose levels increase VOC activity by $50 \%$ or more. VOC multiple compounds and combinations of compounds may exert an inhibitory effect against the target assay organisms and no one set of VOCs 
is essential for bioactivity. But, there is probably synergistic activity with at least one or more compounds in the various VOC mixtures (Eza \& Strobel, 2003).

Volatiles produced by fungi have shown selfgrowth-inhibition. M. albus growth was inhibited by its own VOCs in artifitial mixture (VOCs) of compounds identified in its own environment (Ezra \& Strobel, 2003). Self-inhibition of hyfhal extension and formation of arthrospores in Geatrichum candidum were caused by release of trimethylamine (Robinson et al., 1989).

\section{Bactericide activities of VOC substances produced by microorganisms}

Although volatile antibiotics have been encountered, the literature about effect of VOCs produced by microorganisms against bacterial growth is scarce. $M$. albus VOCs cause 100\% growth inhibition of Escherichia coli, Staphylococcus aureus, Micrococcus luteus and B. subtillis (Strobel et al., 2001).

Volatile short-chain fatty acids from Veilonella species and Bacteroides fragilis control the growth of the enteropathogens Salmonella typhimurium, S. enteritidis, Escherichia coli and Pseudomonas aeroginosa (Hinton Junior \& Hume, 1994; Wrigley, 2004).

Interactions among bacterial species are mostly due to cell-to-cell communication system and quorum sensing to monitor their population density (Ryan \& Dow, 2008) which contributes to virulence, antibiotic production and biofilm formation. Interacting bacteria can sense signal molecules that they do not synthesize, thereby eavesdropping on signaling by other organisms in their immediate environment. Several signal molecules produced by bacteria have been described (Kai et al., 2009).

\section{VOC identification with fungicidal activities using GC/MS}

The mixture of substances also predominates in VOCs with fungicidal activities.

\section{From bacterial isolates}

Zou et al. (2007), found 38 volatile compounds produced by isolated soil bacteria. Twenty-nine commercial compounds with the same chemical structure as the bacterial volatiles were tested. Among them, acetamide, benzaldehyde, benzothiazole, 1-butamine, methanamine, phenylacetaldehyde and 1-decene showed antifungal activity against Paecillomyces lilacinus and Pochonia chlamydosporia. Arrebola et al. (2010), found that the major VOC molecules produced by Bacillus subtillis $(46 \%)$ and B. amyloliquefaciens ( $97 \%$ ) with fungicidal activity were ketones.
VOCs from Paenibacillus polymyxa, B. subtilis and B. pumillus that showed fungal growth inhibition of $F$. oxysporum, $F$. graminerum, $S$. sclerotiorum, B. cinerea, C. kikuchii, A. brassicae, A. solani, A. citrulina, P. arachoidicula, $R$. solani, V. dahliae (Table 2) had in common the compounds: 2,4 decadienal, diethylphthalate, n-hexadecanone acid, oleic acid. However, several species of specific bacterial VOC molecules were also encountered (Liu et al., 2008).

Two antifungal compounds from Streptomyces platensis F-1 VOCs were phenylethyl alcohol and (+)-epibicyclesesquiphellandrene (Wan et al., 2008).

\section{From fungal isolates}

From Muscodor albus about 20 VOC molecules were identified and the most abundant compounds were 1butanol, 3-methyl-acetate. Collectively, the esters constituted the highest percentage of compounds, followed by alcohols, acids, lipids and ketones. The most effective class of inhibitory compounds tested against fungi was the esters, of which 1-butanol, 3-methyl-acetate was the most biologically active, reducing growth of Pythium ultimum, Rhizoctonia solani, Tapesia yallundae, Xylaria sp. by $100 \%$, Sclerotinia sclerotiorum and Cercospora beticola by about $93 \%$ and Fusarium solani by $45 \%$ (Strobel et al., 2001). VOCs analysed in the air space above $M$. albus mycelium grown on rye grain with five apples showed that 2-methyl-1-butanol and isobutyric acid were the major volatile compounds (Mercier \& Jimenez, 2004).

The fungus Kyu-w63 which suppresses the development of wheat powdery mildew caused by Blumeria graminis f. sp. tritici produced two volatile substances 5pentyl-2-furaldehyde and 5-(4-pentenyl)-2-furaldehyde under nutrient-rich culture conditions. The synthesized 5pentyl-2-furaldehyde naturally produced by the fungus Kyuw63, revealed antifungal activity against three others pathogens besides Blumeria graminis f. sp. tritici: Fusarium oxysporum f. sp. lycopersici, Colletotrichum fragariae, Botrytis cinerea (Motoo et al., 2004).

\section{Changing concepts on biological control of plant pathogens and threats of introducing a biological agent into rhizosphere}

Parasitism has been the major criterion to select a candidate microorganism for biological control of plantparasitic nematodes for a long time. Thus the best known agents, either bacterial (Pasteuria spp.) or fungal (Arthrobotrys spp., Paecilomyces lilacinus, Pochonia chlamydosporia etc), have a parasitic or predator 
relationship to the nematode. Trichoderma spp. is a known biocontrol agent against plant-fungus diseases and attempts have been made to use them to control plant parasitic nematodes. Although previous research has shown efficacy of Trichoderma hanzianum in controlling plant-parasitic nematodes, the conviction of its efficacy followed the publication on parasitism to root-knot and cyst nematodes (Seifullah \& Thomas, 1996; Sahebani \& Hadavi, 2008). After strong evidence of efficacy of endophytic bacteria and rhizobacteria on nematode control in the late 1980's, the concept of antagonism as a way of controlling nematodes became evident. After the year 2000, with the emphasis on the volatile-producing microorganism research with nematicidal effect, there underwent an enlargement of nematode-biocontrol concepts. The VOCs produced by Muscodor albus, F. oxysporum, among other fungi, as well as many bacterial species discussed previously, resulted in biocontrol and they are antinematode agents.

Similar changing concepts about other plant pathogenic microorganisms, along the years, seems to occur with fungi and bacteria as candidates for biocontrol agents. The hyperparasites fungi may have been the initial criterion for fungus selection as a biocontrol agent and concept enlargement has occurred since then (Koitabashi, 2005).

The antagonistic aspects of VOCs produced by fungi and bacteria against fungal biocontrol agents discussed here poses a concern on the efficacy of introducing biocontrol agents into the plant rhizosphere, especially, Pochonia chlamydosporia, Paecilomyces lilacicus and Arthrobotrys conoides on which some research evidence have been produced. The elimination of these fungi and bacteria antagonistic to fungal biocontrol, before introducing the biocontrol agents into the field through solarization or fumigation (Cook \& Baker, 1983), may assure their success on reducing plantnematode populations or fungi.

\section{Soil fungistasis involving VOCS from microorganisms}

Soil fungistasis is a widespread phenomenon. Although fungistatic intensity varies with the physical and chemical properties of soil (Qian \& Johnson, 1987; Mondal \& Hyakumachi, 1998; Alabouvette, 1999), factors such as microbial community composition is a determining factor for it (Boer et al., 2003). Single microbial species result in less suppression against colonization by Fusarium oxysporum f. sp. raphani (Toyota et al., 1996). The implication of microorganisms in soil fungistasis has been mostly by limiting available carbon or producing antifungal compounds. These compounds are produced by a wide range of soil microorganisms (Liebman \& Epstein, 1992; Burgess et al., 1999; Behal, 2000). Few studies have focused on volatile inhibition compounds. Xu et al. (2004), found volatiles of all 146 tested soils exhibiting strong antifungal activity resulting in $50 \%$ reduction in spore germination and hyphal extension of three fungi. Zou et al. (2007) found that $32 \%$ of 1018 randomly selected bacteria produced fungistatic volatiles.

Volatiles of rhizobateria and of phytopathogenic bacteria exert fungistatic effects for example, on the growth of phytopathogenic fungi such as Verticillium dahliae, Sclerotinia sclerotiorum and $R$. solani. This adds an additional feature to the antagonistic potential of plantgrowth promoting bacteria and is of agricultural interest (Kai et al., 2009). All of the bacterial cultures tested by Mackie \& Wheatley (1999), produced VOCs that could influence the growth of at least one fungal species, this suggests that the occurrence of VOCs mediates interactive events which could be widespread in soils.

\section{VOCS promote the enlargement of the antagonistic studies with co-existent microorganisms}

The evidence of VOCs on the growth of co-existent microorganisms broaden the research goals of the studies of antagonistic interaction of microorganisms in the same site, which have been mostly focused, on water-soluble substance toxicity. The easy dissemination of VOCs by soil porosity expands their area of influence. In addition, the normal soil abundance of bacterial species and the evidence herein of the strong VOC antagonism of many bacterial species to soil fungi and nematodes address VOCs as an additional approach for research goals regarding suppressiveness studies on plant pathogenic soil fungi and nematodes which strengthen the role of soil suppression to those microorganisms.

VOCs produced by one organism could enhance its status by affecting the physiology of other competitor organisms causing them to function at a slight disadvantage (Wheatley, 2002).

\section{Outlook and future perspectives on research}

Although soil fungi and bacteria are known to produce VOCs (Left \& Fierer, 2008), their VOC antagonic to plant-pathogenic microorganisms are rarely studied which needs to be expanded due to a variety of soil types and conditions in world agriculture. Thus the number of tested bacterial and fungal species able to produce VOCs against other microorganisms, especially those which cause plant diseases, have to be expanded through sample 
collections in diversified environments and soil types. Resident microorganisms in the vicinity of the infection sites should be more carefully studied as to VOC production and their antagonism to the causal disease organism. The studies on the production of VOCs by microorganisms antagonic to plant-pathogenic bacteria needs to be emphasized. For example, the fungal VOCs may limit the bacterial growth or the resulting disease progress by its infection of the plant. There is a need for a better evaluation of the effects of fungal and bacterial VOCs from soil on the soil fungistasis or suppressiveness to plant diseases caused by nematodes, fungi and bacteria. The resulted knowledge about species efficient for the increasing suppressiveness will help producers to capitalize on this important and greatly underutilized pest management tactic. The role of nonpathogenic organisms in the plant-disease complex could be better understood by the studies of VOCs produced by each of them in their antagonistic interaction. Studies on efficient analog molecules from naturally occurring microorganism VOCs against plant-pathogenic microorganisms should be emphasized, which might become a commercial molecule for farmer use in the control of plantpathogenic microorganisms. But care should be taken regarding potential damage to the ozone layer of the atmosphere by the VOC molecules produced by microorganisms which should be examined to avoid their possible extensive uses of the damaged molecules in agriculture as a control tactic for plant-pathogenic organisms as well as to understand the importance of the microorganism activity on the ozone layer depletion.

Researchers should explore the potential of identified microbial isolates and their VOCs for the control of plant-parasitic nematodes in greenhouse and field trials by using either bacteria or fungi by themselves or in combination with other methods such as organic amendments.

The evidence of antagonistic microorganisms of the main biocontrol agent fungi against nematodes strengthen the views of associating tactics for future research to eliminate or change their antagonistic population in the field before the introduction of the biocontrol agent.

VOC research involving plant pathogens is in its infancy and advances are need to the benefit of agriculture science and crop production.

\section{REFERENCES}

LABOUVETTE, C. Fusarium wilt suppressive soils: an example of disease suppressive soil. Australasia Plant Pathology, Collingwood, v.28, p.57-64, 1999.
ARREBOLA, E.; SIVAKUMAR, D.; KORSTEN, L. Effect of volatile compounds produced by Bacillus strains on postharvest decay in citrus. Biologicol Control, Orlando, v.53, p.122-128, Apr. 2010.

BEHAL, V. Bioactive products from Streptomyces. Advances Applied Microbiology, Washington, v.47, p.113-156, 2000.

BOER, W. de; VERHEGGEN, P.; KLEIN-GUNNEWIEK, P.J.A.; GEORGE, A.K.; JOHANNES, A.V. Microbial community composition affects soil fungistasis. Applied Environmental and Microbiology, Washington, v.69, p.835-844, Feb. 2003.

BRUCE, A.; STEWART, D.; VERRALL, S.; WHEATLEY, R.E. Effect of volatiles from bacteria and yeast on the growth and pigmentation of sapstain fungi.

International Biodeterioration \& Biodegradation, Birmingham, v.51, p.101-108, Mar. 2003.

BURGESS, J.G.; JORDAN, E.M.; BREGU, M.; MEARNSSPRAGG, A.; BOYD, K.G. Microbial antagonism: a neglected avenue of natural products research. Journal of Biotechnology, Amsterdam, v.70, p.27-32, 1999.

COOK, R.J.; BAKER, K.F. The nature and practice of biological control of plant pathogens. Saint Paul: American Phytopathological Society, 1983.

DENNIS, C.; WEBSTER, J. Antagonistic properties of species-groups of Trichoderma: II. production of volatile antibiotics. Transaction Mycological Society, London, v.57, p.41-48, 1971.

DUDAREVA, N.; NEGRE, F.; NAGEGOWDA, D.A.; ORLOVA, I. Plant volatiles: recent advances and future perspectives. Critical Reviews in Plant Science, Philadelphia, v.25, p.417-440, Oct. 2006.

EZRA, D.; STROBEL, G.A. Effect of sustrate on the bioactivity of volatile antimicrobials produced by Muscodor albus. Plant Science, Shannon, v.165, p.12291238, Dec. 2003.

FERNANDO, W.G.D.; RAMARATHNAM, R.; KRISHNAMOORTHY,A.S.; SAVCHUK, S.C. Identification and use of potential bacterial organic antifungal volatiles in biocontrol. Soil Biology \& Biochemistry, Oxford, v.37, p.955-964, May 2005. 
FIDDAMAN, P.J.; ROSSAL, S. Effect of substrate on the production of antifungal volatiles from Bacillus subtilis. Journal of Applied Bacteriology, Oxford, v.76, p.395-405, Apr. 1994.

FREIRE, E.S.; CAMPOS, V.P.; OLIVEIRA, D.F.; POHLIT, A.M.; NOBERTO, N.P.; FARIA, M.R.; PINHO, R.S.C.; REZENDE, E.L.; PFENNING, L.H. Volatile substances on the antagonism between fungi, bacteria and Meloidogyne incognita and potentially fungi for nematode control. Journal of Nematology, Hanover, 2010. In press.

GU, Y.Q.; MO, M.H.; ZHOU, J.P.; ZOU, C.S.; ZHANG, K.Q. Evaluation and identification of potential organic nematicidal volatiles from soil bacteria. Soil Biology \& Biochemistry, Oxford, v.39, p.2567-2575, Oct. 2007.

HINTON JUNIOR, A.; HUME, M.E. Antibacterial activity of the metabolic by - products of a Veillonella species and Bacterioides fragilis. Anaerobe, n.1, p.121-127, Apr. 1994.

HUANG, Y.; XU, C.; MA, L.; ZHANG, K.; DUAN, C.; MO, M. Characterization of volatiles produced from Bacillus megaterium YFM 3.25 and their nematicidal activity against Meloidogyne incognita. European Journal of Plant Pathology, Dordrecht, v.126, p.417-422, Jan. 2010.

ISODOROV, V.; JDANOVA, M. Volatile organic compounds from leaves litter. Chemosphere, Davis, v.48, n.9, p.975-979, Sept. 2002.

KAI, M.; EFFMERT, U.; BERG, G.; PIECHULLA, B. Volatiles of bacterial antagonists inhibit mycelial growth of the plant pathogen Rhizoctonia solani. Archives Microbiology, Paris, v.187, p.351-360, May 2007.

KAI, M.; HAUSTEIN, M.; MOLINA, F.; PETRI, A.; SCHOLZ, B.; PIECHULLA, B. Bacterial volatiles and their action potential. Applied Microbiology and Biotechnology, Seoul, v.81, p.1001-1012, Jan. 2009.

KESSELMEIER, J.; STAUDT, M. Biogenic volatile organic compounds (VOC): an overview on emission, physiology and ecology. Journal of Atmospheric Chemistry, v.33, n.1, p.23-88, May 1999.

KNUDSEN, J.T.; GERSHENZON, J. The chemistry diversity of floral scent. In: DUDAREVA, N.; PICHERSKY, E. (Eds.). Biology of floral scent. Boca Raton: CRC, 2006. p. 27-52.
KOITABASHI, M. New biocontrol method for parsley powdery mildew by the antifungal volatiles-producing fungus Kyu-w63. Journal of Gen Plant Pathology, Kyoto, v.71, p.280-284, Aug. 2005.

LACEY, L.A.; NEVEN, L.G. The potential of the fungus Muscodor albus as a microbial control agent of potato tuber moth (Lepidoptera: Gelechiidae) in stored potatoes. Journal of Invertebrate Pathology, Riverside, v.91, p.195-198, Mar. 2006.

LEFT, J.W.; FIERER, N. Volatile organic compound (VOC) emissions from soil and litter samples. Soil Biology $\boldsymbol{\&}$ Biochemistry, Oxford, v.40, n.7, p.1629-1636, July 2008.

LIEBMAN, J.A.; EPSTEIN, L. Partial characterization of volatile fungistatic compounds from soil.

Phytopathology, Saint Paul, v.84, p.442-446, Feb. 1994.

LIU, W.; WU, W.; ZHU, B.; DU, Y.; LIU, F. Antagonistic activities of volatiles from four strains of Bacillus spp. and Paenibacillus spp. against soil-borne plant pathogens. Agricultural Sciences in China, Beijing, v.7, n.9, p.1104-1114, Sept. 2008.

MACKIE, A.E.; WHEATLEY, R.E. Effects and incidence of volatile organic compound interactions between soil bacterial and fungal isolates. Soil Biology $\boldsymbol{\&}$

Biochemistry, Oxford, v.31, p.375-385, Mar. 1999.

MERCIER, J.; JIMÉNEZ, J.I. Control of fungal decay of apples and peaches by the biofumigant fungus Muscodor albus. Postharvest Biology and Technology, Pullman, v.31, p.1-8, Jan. 2004.

MONDAL, S.N.; HYAKUMACHI, M. Carbon loss and germinability, viability, and virulence of chlamydospores of Fusarium solani $\mathrm{f}$. sp. phaseoli after exposure to soil at different $\mathrm{pH}$ levels temperatures and matric potentials. Phytopathology, Saint Paul, v.88, p.148-155, 1998.

MOORE-LANDECKER, E.; STOTZKY, E. Inhibition of fungal growth and sporulation by volatile metabolites from bacteria. Canadian Journal of Microbiology, Ottawa, v.18, p.957-962, July 1972.

MOTOO, K.; KAJITAN, Y.; HIRASHIMA, K. Antifungal substances produced by fungal strain Kyu-w63 from wheat leaf and its taxonomic position. Journal of General Plant Pathology, Kyoto, v.70, p.124-130, Apr. 2004. 
PICHERSKY, E.; NOEL, J.P.; DUDAREVA, N. Biosynthesis of plant volatiles: nature's diversity and ingenuity. Science, Washington, v.311, p.808-811, Feb. 2006.

QIAN, P.; JOHNSON, L.F. Chemical and physical soil characteristic related to lysis of oospores of Pythium ultimum. Phytopathology, Saint Paul, v.77, p.1062-1066, Jan. 1987.

RIGA, E.; LACEY, L.A.; GUERRA, N. Muscodor albus, a potential biocontrol agent against plant-parasitic nematodes of economically important vegetable crops in Washington State, USA. Biological Control, Orlando, v.45, p.380-385, June 2008.

ROBINSON, P.M.; McKEE, N.D.; THOMPSON, L.A.A. Autoinhibition of germination and growth in Geotrichum candidum. Mycological Research, London, v.93, n.2, p.214-222, Sept. 1989.

RYAN, R.P.; DOW, J.M. Diffusible signals and interspecies communication in bacteria. Microbiology, Cambridge, v.154, p.1845-1858, July 2008.

SAHEBANI, N.; HADAVI, N. Biological control of the root-knot nematode Meloidogyne javanica by Trichoderma harzianum. Soil Biology \& Biochemistry, Oxford, v.40, p.2016-2020, Aug. 2008.

SCHULZ, S.; DICKSCHAT, J.S. Bacterial volatiles: the smell of small organisms. Natural Product Reports, Cambridge, v.24, p.814-842, Apr. 2007.

SEIFULLAH, P.; THOMAS, B.J. Studies on the parasitism of Globodera rostochiensis by Trichoderma harzianum using low temperature scanning electron microscopy. Afro-Asian Journal of Nematology, v.6, p.117-122, 1996.

SIKORA, R.A.; BRIDGE, J.; STARR, J.L. Management practices: an overview of integrated management technologies. In: LUC, M.; SIKORA, R.A.; BRIDGE, J. Plantparasitic nematodes in subtropical and tropical agriculture. 2.ed. Wallingford: CAB International, 2005. 871p.

STOTZKY, G.; SCHENCK, S. Volatile organic compounds and microorganisms. CRC Critical Review of Microbiology, v.4, p.333-382, May 1976.
STROBEL, G.A.; DIRKSE, E.; SEARS, J.; MARKWORTH, C. Volatile antimicrobials from Muscodor albus, a novel endophytic fungus. Microbiology, Cambridge, v.147, p.2943-2950, Nov. 2001.

TOYOTA, K.; RITZ, K.; YOUNG, I.A. Microbiological factors affecting colonization of soil aggregates by Fusarium oxysporum f. sp. raphani. Soil Biology \& Biochemistry, Oxford, v.28, p.1513-1521, Oct./Nov. 1996.

VESPERMANN, A.; KAI, M.; PIECHULLA, B. Rhizobacterial volatiles affect the growth of fingi and Arabidopsis thaliana. Applied and Environmental Microbiology, Washington, v.73, n.17, p.5639-5641, June 2007.

VOISARD, C.; KEEL, C.; HAAS, D.; DÉFAGO, G. Cyanide production by Pseudomonas fluorescens cells hepls suppress black root rot of tobacco under gnotobiotic conditions. The EMBO Journal, v.8, n.2, p.351-358, Feb. 1989.

WAN, M.; LI, G.; ZHANG, J.; JIANG, D.; HUANG, H. Effect of volatile substances of Streptomyces platensis F-1 on control of plant fungal diseases. Biological Control, Orlando, v.46, p.552-559, Sept. 2008.

WHEATLEY, R.E. The consequences of volatile organic compound mediated bacterial and fungal interactions. Antonie Van Leeuwenhoek, Amsterdam, v.81, p.357-364, Nov. 2002.

WRIGLEY, D.M. Inhibition of Clostridium perfringens sporulation by Bacterioides fragilis and short-chain fatty acids. Anaerobe, Mankato, v.10, p.295-300, Sept. 2004.

XU, C.; MO, M.; ZHANG, L.; ZHANG, K. Soil volatile fungistasis and volatile fungistatic compounds. Soil Biology \& Biochemistry, Oxford, v.36, p.1997-2004, Dec. 2004.

ZOU, C.; MO, M.; GU, Y.; ZHOU, J.; ZHANG, K. Possible contributions of volatile-producing bacteria to soil fungistasis. Soil Biology \& Biochemistry, Oxford, v.39, p.2371-2374, Sept. 2007. 